\title{
Implementasi Jaringan Syaraf Tiruan untuk Menentukan Kepribadian Mahasiswa Menggunakan Algoritma Perceptron
}

\author{
Lucky Lhaura Van FC ${ }^{1}$, Fajrizal $^{2}$, Lisnawita ${ }^{3}$ \\ 1,2,3 Program Studi Teknik Informatika Fakultas Ilmu Komputer Universitas Lancang Kuning \\ 1,2,3 Jl. Yos Sudarso KM. 8 Rumbai, Pekanbaru, Riau, telp. 08117532015 \\ e-mail: ${ }^{1}$ lucky@unilak.ac.id, ${ }^{2}$ fajrizal@unilak.ac.id, ${ }^{3}$ lisnawita@unilak.ac.id
}

\begin{abstract}
Abstrak
Setiap orang yang mempunyai kepribadian sesuai dengan lingkungan sekitarnya agar terjalin hubungan yang baik. Pada lingkungan Fakultas Ilmu Komputer Universitas Lancang Kuning, peneliti melakukan evaluasi akademik ketika melakukan pengajaran ada beberapa kelompok mahasiswa dengan gaya belajar yang berbeda, beberapa mahasiswa sulit aktif didalam kelas, mengenai gaya belajar ini sudah pernah kita lakukan penelitiannya, ternyata gaya belajar mempunyai korelasi dengan kepribadian mahasiswa dimana terciptanya hubungan yang baik antar dosen dan mahasiswa akan memberikan dampak yang positif karena mahasiswa tidak akan malas lagi untuk mengikuti materi yang di ambil mahasiswa tersebut dan dosen juga dapat menentukan cara mengajar yang tepat berdasarkan kepribadian mahasiswa tersebut. 4 tipe kepribadian mahasiswa yaitu guardian, artisan, idealist dan rational. Dalam penelitian ini ada 30 orang responden yang harus mengisi kuisioner. Kemudian diolah komputerisasi yang berbasis JST algoritma Perceptron.. Hasil dari penelitian adalah 5 mahasiswa dengan kepribadian Guardian, 11 Artisan, 11 Idealist dan 3 Mahasiswa Rational.
\end{abstract}

Kata Kunci : Jaringan Syaraf Tiruan, Tipe Kepribadian, Perceptron

Abstract

Every person who has a personality following the surrounding environment to establish a good relationship. In the environment of the Faculty of Computer Science,Universitas Lancang Kuning, researchers conduct academic evaluations when conducting teaching there are several groups of students with different learning styles, some students find it difficult to be active in class, about this learning style we have already done the research, it turns out learning styles have a correlation with personality students where the creation of a good relationship between lecturers and students will have a positive impact because students will no longer be lazy to follow the material taken by the student and the lecturer can also determine the right way of teaching based on the student's personality. The 4 personality types of students are guardian, artisan, idealist and rational. In this study, 30 respondents had to fill out a questionnaire. Then computerized based on the ANN algorithm Perceptron. The results of the study were 5 students with Guardian personalities, 11 Artisan, 11 Idealist and 3 Rational Students

Keywords : Artificial Neural Networks, Personality Types, Perceptron

\section{Pendahuluan}

Kepribadian merupakan hal yang harus diketahui dan dipelajari oleh siapapun karena sangat berkaitan dengan lingkungan sosial seseorang. Setiap orang yang mempunyai kepribadian sesuai dengan lingkungan sekitarnya, apabila lingkungan sekitarnya baik maka dia akan memiliki kepribadian yang baik dan begitu pula sebaliknya. Pentingnya dosen mengetahui 
kepribadian mahasiswa adalah sebagai salah "satu sarana untuk menilai mahasiswa secara softskill, dimana akan ada perbedaan tindakan untuk tiap-tiap masukan dalam kepribadian mahasiswa, dan juga dapat menjalin komunikasi yang baik agar terciptanya hubungan yang baik antar dosen dan mahasiswa, sehingga ada faktor Humanity antara dosen dan mahasiswa sehingga dalam penyampaian materi mahasiswa dapat menyerapnya dengan baik.

Kemajuan teknologi komputer juga berperan penting dalam memberikan dukungan kepada setiap insan untuk menyelesaikan berbagai macam permasalahan, salah satu bagian dari bidang ilmu komputer adalah Jaringan Syaraf Tiruan (Artificial Neural Networks) yang merupakanbagian dari ilmu kecerdasan buatanatau Artificial intelegence yang sudah banyak digunakan untuk menyelesaikan berbagai macam masalah yang berhubungan dengan prediksi atau peramalan. "Diantaranya adalah penerapan jaringan syaraf tiruan dengan menggunakan algoritma perceptron, yang mana dipenelitian ini Jaringan Syaraf Tiruan berfungsi untuk memprediksi kepribadian mahasiswa. Jaringan Syaraf Tiruan atau yang disingkat JST, merupakan suatu sistem komputasi dimana pada arsitektur dan operasinya dipahami dari pengetahuan tentang sel syaraf biologis di dalam otak, yang berupa bagian dari representasi buatan dari dalam otak manusia yang mencoba menstimulasikansuatu proses pembelajaran pada otak tersebut. Selama ini banyak Jaringan Syaraf Tiruan yang diterapkan untuk menyelesaikan berbagai masalah tentang penentuan pola gizi, pengenalan suara, pengenalan pola, pengenalan sinyal, medalami karakter guna pemahaman dokumen dan permasalahan lainnya.

Penelitian serupa juga pernah dilakukan oleh Y. A. Lesnussa,dkk[1] menunjukkan bahwa korelasi antara Nilai Ujian Nasional dan total nilai siswa semester satu kelas sepuluh cukup baik dengan nilai error yang kecil. Penelitian Lucky Lhaura Van FC [2] Dalam mengelompokkan gaya belajar mahasiswa bisa di ketahui dengan tingkat performance 0,33 dan dicapai pada epoch 100. Penelitian Oleh Khairil, dkk [3]Terdapat beberapa jenis citra data praktik memberi efek level ketepatan sistem pendalaman type golongan darah yang digunakan dalam jaringan syaraf tiruan perceptron. Banyaknya cara yang dapat dilakukan dalam pegujian memberikan manfaat perceptron dalam mengkalkulasikan nilai bobot alpha 1 dan threshold 0 , huruf hijaiyah dengan jumlah Epoch yang dihasilkan menjadi berbeda [4][5].

Penelitian Yuma Nagao,dkk [6] hasil menunjukkan bahwa metode yang digunakan dapat mengklasifikasikan ekspresi MathML dengan akurasi yang lebih tinggi dar ipada metode berbasis SVM. Penelitian oleh Musli Yanto[7] Algoritma Perceptron dalam menentukan kelulusan sidang skripsi tidak mengalami kesalahan sehingga mampu dalam pengambilan keputusan.[8] hasil menunjukkan bahwa algoritma pelatihan ex-situ Berjalan dengan baik, dimana ketika semua perangkat keras yang tidak ideal dapat ditemukan dan dipertimbangkan dalam model prekursor perangkat lunak jaringan.

Penelitian Fachrie[9] menunjukkan semakin banyak variasi data Multilayer Perceptron (MLP) maka mampu mengklasifikasikan data kinerja Satpam dengan akurasi tertinggi sebesar $97,75 \%$ dan rata-rata akurasi tertinggi sebesar 96,59\%.

Dari penelitian terdahulu yang sudah dibahas sebelumnya maka peneliti memberikan perbedaan penelitian penentuan kepribadian yaitu belum adanya penerapan algoritma perceptron sebagai alat untuk melatih dan menguji data dimana dosen bisa mengetahui pola ajar kepribadian mahasiswanya sehingga nantinya bisa menjadikan ini basis untuk mengembangankan metode pembelajaran .

\section{Metode Penelitian}

Upaya dalam mencari sebuah hasil dengan menggunakan metode ilmiah merupakan tujuan dari sebuah penelitian. Adapun unsur penting dari sebuah penelitian harus memiliki target sebuah penelitian. 


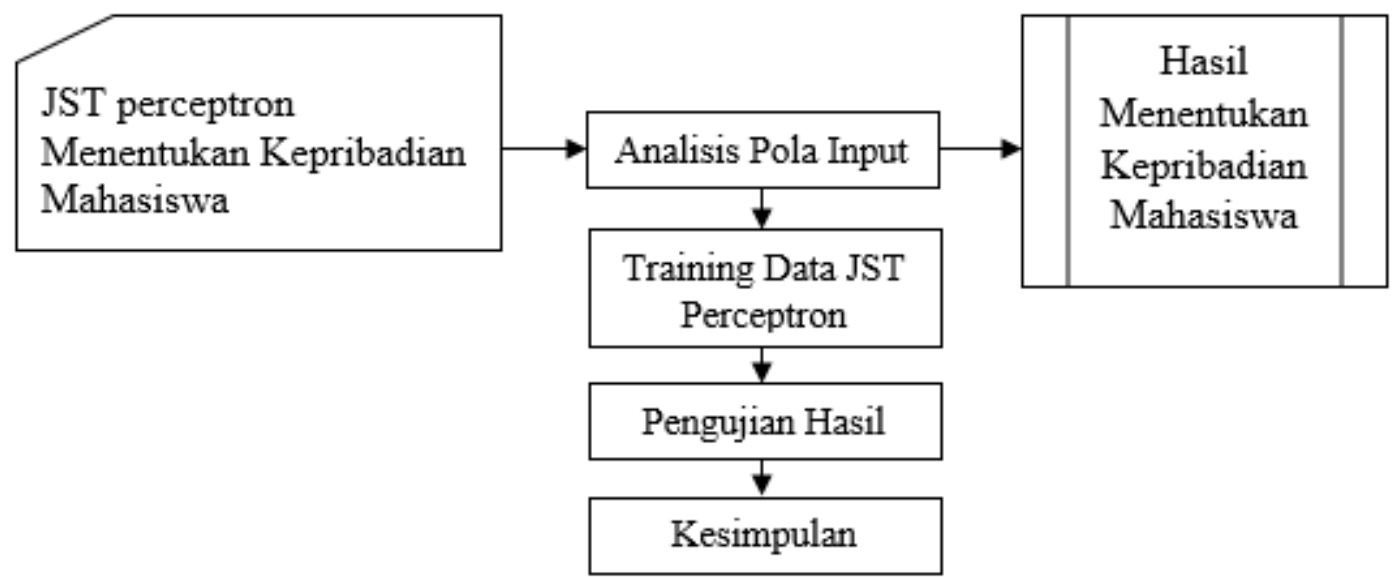

Gambar 1. Metode Penelitian

1. JST Perceptron menentukan Kepribadian Mahasiswa

Mengumpulkan beberapa data yang berkaitan dengan penelitian untuk mendapatkan informasi yang diperlukan mengenai kriteria input yang akan di masukan ke dalam pola

2. Analisis Pola Input

Mengelompokkan kriteria yang sudah didapatkan pada pengumpulan data, dimana ada 23 input dan 4 output

3. Training Data JST Perceptron

Pada Saat Training atau Data Latih yang digunakan adalah perpola masukan yang akan di uji nantinya.

4. Pengujian Hasil

Setelah dilakaukan trainingdata set maka langkah selanjutnya adalah menguji menguji hasil prediksi kepribadian mahasiswa

5. Kesimpulan

Pada tahap ini kita bisa mendiskripsikan dan mendapatkan hasil penelitian dan dibantu denhgan ouput berupa grafik.

\subsection{Lokasi Dan Waktu Penelitian}

Universitas Lancang Kuning adalah tempat dalam melaksanakan penelitian. Study kasus pada penelitian ini adalah Fakultas Ilmu Komputer Prodi Teknik Infromatka konsentrasi Artificial Intelligent. Penelitian ini dimulai pada tanggal Oktober 2019 sampai dengan Januari 2020.

\subsection{Penggunaan Data}

1. Data Primer

Data primer didapat langsung dari hasil wawancara dengan ibu Dra. Erni Yulial, Psi selaku Psikolog yang beralamat di Jalan Pelita Gang Nusa Indah No.5 Pekanbaru.

2. Data Sekunder

Data yang sudah dikumpulkan dengan tujuan menyelesaikan sebuah penelitian yang sedang berlangsung. Dalam data sekunder, buku artikel, jurnal, literature 
dan situs di internet merupakan sumber yang menjadi referensi dan akan dituangkan didalam daftar pustaka

\subsection{Teknik Pengumpulan Data}

Pada saat melakukan penelitian ini, dilakukan suatu cara untuk mencari suatu kebenaran dari sistem yang sedang berlangsung dan mengumpulkan seluruh data yang objektif dan dapat dipertanggung jawabkan dalam melakukan pembuatan laporan dikemudian hari. Dalam hal ini peneliti menggunakan metode penelitian sebagai berikut:

\section{Studi Lapangan}

a. Pengamatan, adalah teknik yang dilakukan untuk pengumpulan data dengan cara mengamati serta mencatat informasi mengenai pola kepribadian mahasiswa di Fakultas Ilmu Komputer Universitas Lancang Kuning.

b. Wawancara adalah sebuah teknik yang dilakukan dengan mengadakan wawancara langsung dengan Psikolog mengenai kepribadian mahasiswa.Studi Pustaka.

Dalam kajian studi pustaka diperoleh data melalui beberapa referensi seperti buku - buku yang berkenaan dengan persoalan dalam penelitian.

\section{Studi Labor}

Pada penelitian ini akan dilakukan sebuah pengujian pada Software Matlab. Untuk membaca temuan penelitian.

\section{Hasil dan Pembahasan}

Pada proses menganalisa data, tim peneliti telah menyampaikan tujuan dan tata cara penelitian kepada objek penelitian. Jenis penelitian ini merupakan penelitian transpara dimana nama dari objek penelitian di tulis dalam kuisioner dengan kata lain tidak ada pemberian kode sebagai pengganti nama objek penelitian. Olehkarena itu, semua informasi yang dibutuhkan dalam pegumpulan data tentang objek penelitian dijamin kerahasiaannya.

Dalam tahap penelitian, setelah pengumpulan data, langkah selanjutnya adalah penganalisaan data. Adapun tahapannya sebagai berikut:

1. Editing, dalam penganalisaan data editing tim penelitian memastikan bahwa kuisioner yang telah di isi oleh objek penelitian lengkap, apakah sudah sesuai dengan arahan yang diberikan oleh tim peneliti.

2. Coding, merupakan tahap dimana peneliti memberi kode tertentu dalam kuisioner sehingga dapat memudahkan tim peneliti dalam pengisisan tabulasi dan analisa data.

3. Tabulating, merupakan tahapan dalam memudahkan peneliti dalam peganalisaan data dan pengolahan data serta dalam meyimpulkan sebuah hasil penelitian. 23 pernyataan yang merupakan bagian dari tipe kepribadian guardian yaitu nomor 4, 8, 12, 15,19, tipe kepribadian artisan 2, 5, 9, 13, 18, 21, 23 , tipe kepribadian idealist $3,6,10,14,17,22$, dan tipe kepribadian rational yaitu pada nomor $1,7,11,16,20$ dan akan dihitung total pada setiap item. Dengan demikian apabila item yang dimaksud memiliki angka yang tinggi artinya semakin bagus nilai pada kepribadian tersebut. Misalnya pada kepribadian artisan, mahasiswa menyetujui pernyataan pada nomor 5, 9, 13, 18, 
21, 23 maka total skornya adalah 6 (karena siswa memilih 6 nomor). Demikian seterusnya. Setelah diperoleh angka yang dimaksud maka data dikalkulasikan kedalam tabel distribsi frekuensi dan persentase

Tipe kepribadian mahasiswa ditentukan oleh nilai yang mereka peroleh.

4. Cloning, tahap ini merupakan pegecekan untuk menghidari kesalahan dalam pengiputan data sehingga data tersebut dapat dianalisa. Sama halnnya dengan tabulating hasil analisa data dapat dilihat melalui tabel distribusi frekensi dan persentase. Jenis pengelompokan karakter kepribadian objek penelitian terdiri dari umur, gender, dan hasil kepribadian. Dalam hal ini, usia objek penelitian berusia rentang 17 hingga 22 tahun. Data dapat dilihat dari tabel dibawah ini:

Tabel 1. Distribusi Frekuensi dan Persentase Karakteristik Responden

\begin{tabular}{|l|c|c|}
\hline \multicolumn{1}{|c|}{ Variabel } & Frekuensi & \% \\
\hline Usia & & \\
17 Tahun & 1 & 3.33 \\
18 Tahun & 12 & 40 \\
19 Tahun & 8 & 26.7 \\
20 Tahun & 4 & 13.3 \\
21 Tahun & 3 & 10 \\
22 Tahun & 2 & 6.67 \\
\hline Jenis Kelamin & & \\
Laki-laki & 20 & 66.7 \\
Perempuan & 10 & 33.3 \\
\hline
\end{tabular}

\subsection{Analisa Pola Input dan Target}

Dalam pemilihan tipe kepribadian pada sistem ini hanya menggunakan 23 pernyataan yang nanti akan dijadikan variabel input, pernyataan tersebut adalah sebagai berikut:

Tabel 2. Pernyataan Untuk Variabel Input

\begin{tabular}{|c|l|}
\hline No & \multicolumn{1}{|c|}{ Pernyataan } \\
\hline 1 & Saya menyukai penjelasan yang didasarkan pada logika. \\
\hline 2 & Saya lebih menyukai ilmu terapan. \\
\hline 3 & $\begin{array}{l}\text { Saya menyukai pembelajaran tentang ide-ide dan moral, dan peroalan yang } \\
\text { nyata dengan demikian masalah dapat saya atasi. }\end{array}$ \\
\hline 4 & $\begin{array}{l}\text { Saya menyukai kelas sesuai denga prosedur dan schedule yang sudah di atur } \\
\text { atau jadwal tidak berubah. }\end{array}$ \\
\hline 5 & Saya selalu terlihat aktif dimanapun. \\
\hline 6 & $\begin{array}{l}\text { Menulis essay merupakan hobi saya karena didalam essay dapat dituangkan ide } \\
\text { dari pemikiran saya }\end{array}$ \\
\hline 7 & Saya dapat menerima materi dengan intelektualitas yang tinggi. \\
\hline 8 & Saya menyukai dosen yang memberi penjelasan secara detail, tepat dan nyata. \\
\hline 9 & $\begin{array}{l}\text { Saya menyukai kegiatan demonstrasi, persentase dan pengalaman belajar lain } \\
\text { yang melibatkan aksi. }\end{array}$ \\
\hline 10 & Saya menyukai materi dengan tema sesuatu dimasa yang akan datang \\
\hline 11 & $\begin{array}{l}\text { Eksperimen, eksplorasi, penemuan, dan pemecahan masalah yang kompleks } \\
\text { merupakan model pembelajaran yang saya suka } .\end{array}$ \\
\hline
\end{tabular}




\begin{tabular}{|c|l|}
\hline 12 & $\begin{array}{l}\text { Saya meyukai materi yang rasional dengan kenyataan berdasarkan } \\
\text { pertimbangan masa lalu dan masa depan }\end{array}$ \\
\hline 13 & Saya senang menceritakan hasil belajar kepada teman lain. \\
\hline 14 & $\begin{array}{l}\text { Saya tidak menyukai perlombaan. Menurut saya perlombaan hanya ada dalam } \\
\text { diri saya. }\end{array}$ \\
\hline 15 & Saya tidak menyukai gambar, lebih menyukai cerita. \\
\hline 16 & Berpikir strategis untuk mencapai tujuan merupakan karakter. \\
\hline 17 & $\begin{array}{l}\text { Saya menyukai kelas karena dosen dan mahasiswa dapat lebih leluasa dalam } \\
\text { berdisksi dengan baik }\end{array}$ \\
\hline 18 & $\begin{array}{l}\text { Dalam mengerjakan tugas, saya lebih suka mecari tahu manfaat yang didapat, } \\
\text { dan hubugan materi yang ada pada saat itu. }\end{array}$ \\
\hline 19 & $\begin{array}{l}\text { Setiap tugas harus terperinci sehingga dapat diketahui manfaat dari tugas } \\
\text { tersebut. }\end{array}$ \\
\hline 20 & $\begin{array}{l}\text { Saya lebih suka memanfaatkan masa untuk membaca dan mencari informasi } \\
\text { atau pengetahuan baru daripada dari orang lain. }\end{array}$ \\
\hline 21 & Saya menyukai kompetisi dan kesempatan untuk bertanding. \\
\hline 22 & Saya lebih menyukai melakukann tugas secara individu daripada berkelompok. \\
\hline 23 & Saya type orang gegabah, mudah jenuh apabila pembelajaran tidak bervariasi \\
\hline
\end{tabular}

Pernyataan diatas dijadikan sebagai input pada training set. Jika jawaban dipilih, sehingga diwakili dengan angka 1, jika tidak diwakili angka 0. Ada 4 jenis output yang diinginkan yaitu $\mathrm{G}$ untuk kepribadian Guardian, A untuk Artisan, I untuk Idealist dan R untuk Rational. Untuk dapat membuat output training set, jika hasil kuisioner bernilai G maka nilai output adalah 0 , jika hasil kuisioner bernilai A maka nilai output adalah -1, jika hasil I maka nilai output 1 dan jika hasil kuisioner bernilai $\mathrm{R}$ maka nilai output nya 0,5 .Penentuan untuk nilai output kita merujuk pada fungsi aktivasi yang digunakan JJ Siang ;2009 [10] menggunakan tipe rosebatt ,algoritma perceptron pertama pada tahun 1962.

Untuk mengidentifikasi tipe kepribadian mahasiswa dalam sebuah kelas dengan valid,dapat dilakukan dengan angket yang telah mereka isi. Pernyataan yang mereka jawab mengindikasikan pada karakter mereka masing - masing. Hasil angket tersebut menunjukkan persentase mahasiswa yang memiliki tipe kepribadian guardian, artisan, idealist dan rational. Setelah itu diolah secara komputerisasi yang berbasis JST. Pola-pola ini akan dipakai training set data untuk mendapatkan target sesuai dengan pola yang diinginkan. Tabel hasil gaya belajar serta desain pola input, output dan desired output seperti tabel 3 berikut ini.

Tabel 3.Rekap Tipe Kepribadian Mahasiswa

\begin{tabular}{|c|l|c|c|}
\hline No & \multicolumn{1}{|c|}{ Tipe Kepribadian } & Frekuensi & P $(\%)$ \\
\hline 1 & Guardian & 5 & 16.667 \\
\hline 2 & Artisan & 11 & 36.667 \\
\hline 3 & Idealist & 11 & 36.667 \\
\hline 4 & Rational & 3 & 10 \\
\hline
\end{tabular}

\subsection{Data Set Training}

Untuk menemuka desain pola input dapat dilakukan melalui Data set training . Data nama - nama objek penelitian dan header kolom input dan output dihilangkan. 
Sehingga data - data tersebut berubah format CVS (Comma Seperated Version) sehingga data training set sudah dapat diaplikasikan. Adapun Data training set pada penelitian dapat dilihat melalui tabel

Tabel 4. Data Set Training

\begin{tabular}{|l|}
\hline $1 ; 0 ; 1 ; 1 ; 0 ; 0 ; 0 ; 1 ; 0 ; 0 ; 0 ; 1 ; 0 ; 0 ; 0 ; 0 ; 0 ; 0 ; 0 ; 0 ; 0 ; 0 ; 0$ \\
\hline $1 ; 0 ; 1 ; 0 ; 1 ; 1 ; 1 ; 1 ; 1 ; 0 ; 1 ; 1 ; 1 ; 0 ; 0 ; 0 ; 1 ; 1 ; 0 ; 0 ; 1 ; 1 ; 0$ \\
\hline $1 ; 0 ; 0 ; 1 ; 0 ; 1 ; 0 ; 1 ; 0 ; 0 ; 0 ; 0 ; 0 ; 0 ; 0 ; 0 ; 0 ; 0 ; 1 ; 0 ; 0 ; 0 ; 0$ \\
\hline $1 ; 0 ; 1 ; 1 ; 1 ; 1 ; 0 ; 1 ; 1 ; 1 ; 1 ; 1 ; 1 ; 0 ; 0 ; 1 ; 0 ; 1 ; 1 ; 0 ; 1 ; 1 ; 1$ \\
\hline $1 ; 1 ; 1 ; 0 ; 1 ; 0 ; 0 ; 1 ; 1 ; 1 ; 1 ; 1 ; 1 ; 0 ; 1 ; 1 ; 1 ; 1 ; 1 ; 0 ; 0 ; 1 ; 1$ \\
\hline $1 ; 0 ; 1 ; 1 ; 1 ; 1 ; 0 ; 1 ; 0 ; 0 ; 1 ; 0 ; 1 ; 0 ; 1 ; 1 ; 1 ; 1 ; 0 ; 0 ; 1 ; 0 ; 0$ \\
\hline $1 ; 0 ; 0 ; 0 ; 1 ; 1 ; 0 ; 0 ; 1 ; 1 ; 1 ; 0 ; 1 ; 1 ; 0 ; 0 ; 0 ; 0 ; 0 ; 1 ; 0 ; 0 ; 1$ \\
\hline $1 ; 0 ; 1 ; 1 ; 0 ; 1 ; 1 ; 1 ; 1 ; 0 ; 1 ; 1 ; 0 ; 1 ; 0 ; 1 ; 1 ; 1 ; 1 ; 0 ; 1 ; 1 ; 1$ \\
\hline $1 ; 0 ; 1 ; 1 ; 1 ; 0 ; 0 ; 1 ; 0 ; 1 ; 1 ; 1 ; 0 ; 0 ; 0 ; 1 ; 1 ; 0 ; 1 ; 0 ; 1 ; 0 ; 1$ \\
\hline $1 ; 1 ; 0 ; 1 ; 0 ; 1 ; 0 ; 1 ; 0 ; 1 ; 1 ; 1 ; 0 ; 0 ; 0 ; 0 ; 1 ; 0 ; 0 ; 1 ; 1 ; 1 ; 1$ \\
\hline $0 ; 1 ; 1 ; 1 ; 0 ; 1 ; 0 ; 1 ; 1 ; 1 ; 1 ; 1 ; 1 ; 1 ; 1 ; 1 ; 1 ; 0 ; 1 ; 1 ; 0 ; 1 ; 0$ \\
\hline $1 ; 1 ; 1 ; 1 ; 0 ; 0 ; 1 ; 1 ; 0 ; 1 ; 0 ; 1 ; 1 ; 0 ; 0 ; 1 ; 0 ; 0 ; 0 ; 1 ; 0 ; 0 ; 1$ \\
\hline $1 ; 0 ; 1 ; 1 ; 0 ; 0 ; 0 ; 1 ; 0 ; 1 ; 1 ; 1 ; 0 ; 0 ; 0 ; 1 ; 0 ; 0 ; 1 ; 0 ; 1 ; 0 ; 1$ \\
\hline $1 ; 0 ; 1 ; 0 ; 1 ; 1 ; 0 ; 1 ; 0 ; 1 ; 0 ; 0 ; 0 ; 1 ; 0 ; 0 ; 1 ; 0 ; 1 ; 0 ; 1 ; 0 ; 0$ \\
\hline $1 ; 1 ; 1 ; 0 ; 0 ; 1 ; 0 ; 1 ; 1 ; 1 ; 1 ; 1 ; 0 ; 1 ; 1 ; 1 ; 0 ; 1 ; 1 ; 0 ; 1 ; 0 ; 1$ \\
\hline $1 ; 0 ; 1 ; 1 ; 0 ; 1 ; 0 ; 1 ; 1 ; 0 ; 0 ; 1 ; 0 ; 1 ; 0 ; 0 ; 1 ; 0 ; 1 ; 1 ; 0 ; 1 ; 1$ \\
\hline $1 ; 1 ; 0 ; 0 ; 0 ; 0 ; 0 ; 0 ; 1 ; 0 ; 1 ; 0 ; 1 ; 0 ; 0 ; 0 ; 1 ; 0 ; 0 ; 0 ; 0 ; 1 ; 1$ \\
\hline $1 ; 0 ; 1 ; 1 ; 0 ; 0 ; 0 ; 1 ; 1 ; 1 ; 1 ; 0 ; 0 ; 1 ; 0 ; 0 ; 1 ; 0 ; 0 ; 0 ; 0 ; 1 ; 1$ \\
\hline $0 ; 0 ; 1 ; 0 ; 0 ; 1 ; 0 ; 1 ; 1 ; 1 ; 1 ; 0 ; 1 ; 1 ; 1 ; 0 ; 0 ; 0 ; 1 ; 0 ; 0 ; 0 ; 1$ \\
\hline $1 ; 1 ; 1 ; 1 ; 0 ; 1 ; 1 ; 1 ; 1 ; 0 ; 0 ; 0 ; 0 ; 0 ; 0 ; 0 ; 1 ; 1 ; 1 ; 0 ; 0 ; 0 ; 1$ \\
\hline $1 ; 0 ; 1 ; 1 ; 1 ; 1 ; 0 ; 0 ; 1 ; 0 ; 1 ; 0 ; 1 ; 0 ; 0 ; 0 ; 1 ; 0 ; 1 ; 0 ; 1 ; 0 ; 1$ \\
\hline $1 ; 0 ; 1 ; 1 ; 1 ; 1 ; 0 ; 1 ; 1 ; 1 ; 1 ; 1 ; 1 ; 1 ; 1 ; 1 ; 1 ; 1 ; 1 ; 1 ; 0 ; 1 ; 0$ \\
\hline $1 ; 0 ; 0 ; 1 ; 1 ; 1 ; 0 ; 1 ; 0 ; 0 ; 1 ; 0 ; 0 ; 0 ; 0 ; 0 ; 1 ; 1 ; 1 ; 1 ; 1 ; 0 ; 1$ \\
\hline $0 ; 0 ; 1 ; 0 ; 0 ; 1 ; 0 ; 1 ; 0 ; 0 ; 1 ; 1 ; 0 ; 0 ; 0 ; 0 ; 0 ; 0 ; 1 ; 0 ; 0 ; 0 ; 0$ \\
\hline $1 ; 0 ; 1 ; 0 ; 0 ; 0 ; 0 ; 1 ; 0 ; 1 ; 1 ; 1 ; 0 ; 0 ; 0 ; 1 ; 0 ; 0 ; 0 ; 0 ; 0 ; 0 ; 0$ \\
\hline $1 ; 0 ; 1 ; 1 ; 0 ; 0 ; 1 ; 1 ; 1 ; 0 ; 1 ; 1 ; 0 ; 1 ; 1 ; 1 ; 1 ; 1 ; 0 ; 1 ; 1 ; 1 ; 1$ \\
\hline $1 ; 0 ; 1 ; 0 ; 0 ; 1 ; 0 ; 1 ; 1 ; 1 ; 1 ; 1 ; 1 ; 0 ; 0 ; 1 ; 1 ; 0 ; 1 ; 0 ; 0 ; 0 ; 1$ \\
\hline $1 ; 1 ; 1 ; 1 ; 0 ; 1 ; 0 ; 1 ; 0 ; 0 ; 1 ; 1 ; 1 ; 0 ; 1 ; 1 ; 1 ; 1 ; 0 ; 1 ; 1 ; 1 ; 1$ \\
\hline $1 ; 1 ; 1 ; 10 ; 1 ; 1 ; 11 ; 1 ; 0 ; 0 ; 1 ; 1 ; 1 ; 1 ; 1 ; 1 ; 0 ; 0 ; 1 ; 1$ \\
\hline $1 ; 1 ; 1 ; 1 ; 0 ; 1 ; 0 ; 1 ; 1 ; 0 ; 1 ; 1 ; 0 ; 1 ; 0 ; 1 ; 1 ; 0 ; 0 ; 0 ; 0 ; 0 ; 1$ \\
\hline
\end{tabular}

\subsection{Arsitektur Tipe Kepribadian Perceptron}

Perceptron merupakan Arsitektur Jaringan Syaraf Tiruan yang dimanfaat terdiri dari node input berjumlah 23 pernyataan yang menjadi pilihan jawaban yang diisi oleh objek penelitian. Jumlah neuron input adalah 1 buah yang mewakili jenis pola tipe kepribadian. 


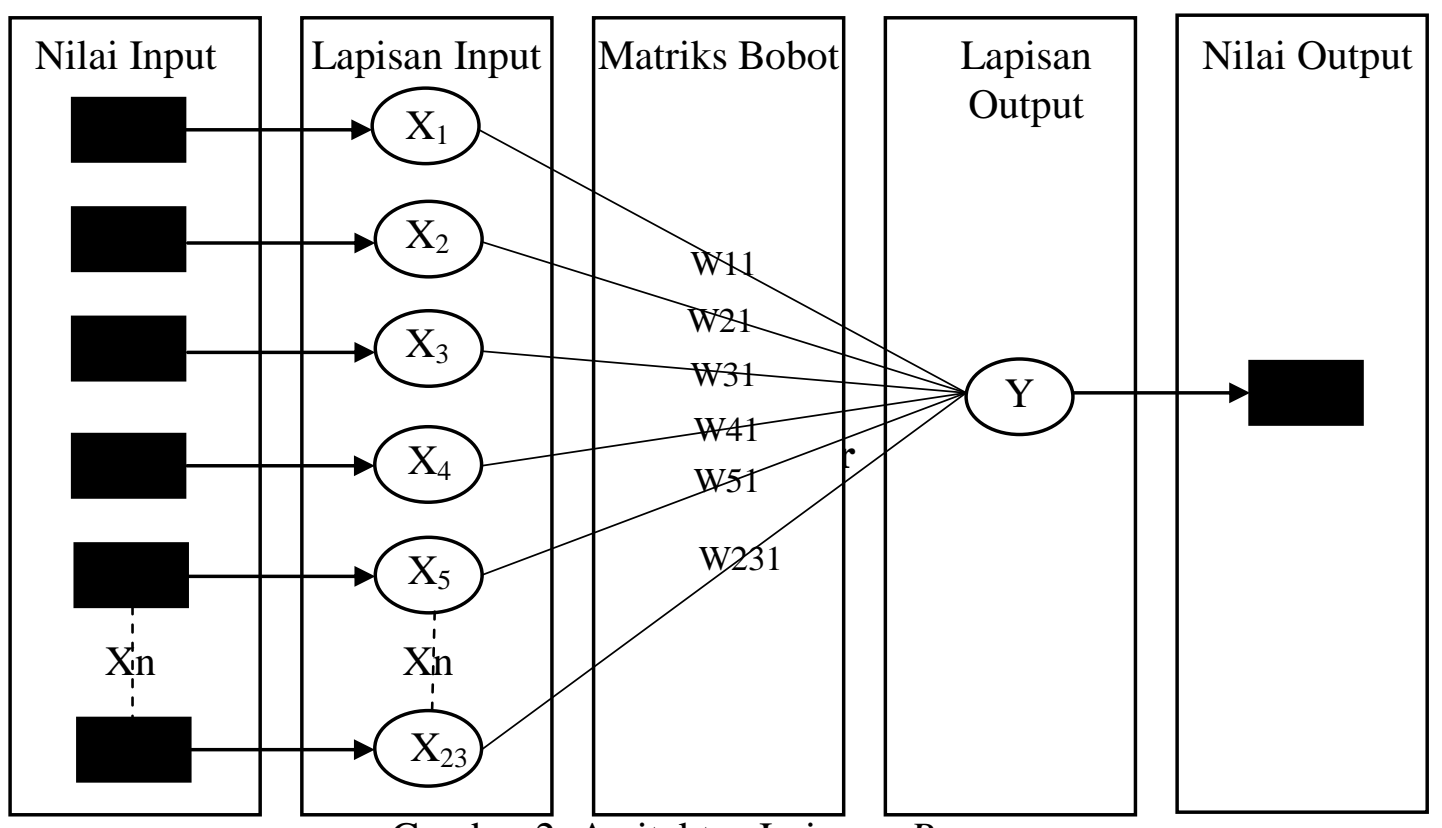

\subsection{Algoritma Perceptron}

Gambar 2. Arsitektur Jaringan Perceptron

Algoritma pelatihan digunakan untuk melatih Jaringan Syaraf Tiruan dengan cara mengajarinya contoh-contoh pola sampai Jaringan Syaraf Tiruan mengenali pola tersebut. Jika output yang dihasilkan tidak sesuai dengan target maka bobot harus di update sampai sesuai dengan target yang diinginkan.

Berikut ini adalah langkah dalam perhitungan algoritma perceptron.

1. Tahap Intilization, mengidentifikasi nilai awal terhadap variabel-variabel yang dibutuhkan seperti nilai input $(\mathrm{x})$, nilai bobot $(\mathrm{w})$, nilai output $(\mathrm{y})$, learning rate $(\alpha)$ dan treshold $(\Theta)$.

2. Tahap Aktivation. Penghitungan angka actual output.

3. Tahap Weight Training, yaitu proses berubahnya nilai bobot dan bias.

4. Tahap Iteration, merupakann lagkah akhir untuk pengujian.

\subsection{Analisa Proses}

Dalam analisa Proses diperlukan penentukan data input, output dan target. Analisa menggunakan algoritma perceptron, berikut adalah proses perhitungan manual dalam penerapan Jaringan Syaraf Tiruan dalam mengidentifikasi Kepribadian Mahasiswa.

\section{Data Ke-1}

Data Input $=1 ; 0 ; 1 ; 1 ; 0 ; 0 ; 0 ; 1 ; 0 ; 0 ; 0 ; 1 ; 0 ; 0 ; 0 ; 0 ; 0 ; 0 ; 0 ; 0 ; 0 ; 0 ; 0$

Target : 0

Algoritma Perceptron:

1. Inisialisasi ( $w 1=w 2=w 3=w 4 \ldots w 23=0 ; \quad b=0 ; \quad \alpha=1 ; \quad \Theta=0$ )

2. Hitung respon untuk unit output

$$
\begin{aligned}
& =0+(1.0)+(0.0)+(1.0)+(1.0)+(0.0)+(0.0)+(0.0)+(1.0)+(0.0)+(0.0)+(0.0)+ \\
& (1.0)+(0.0)+(0.0)+(0.0)+(0.0)+(0.0)+(0.0)+(0.0)+(0.0)+(0.0)+(0.0)+(0.0)) \\
& =0
\end{aligned}
$$


Fungsi aktivasi

$$
\mathrm{Y}=0,\left[\begin{array}{c}
1, \text { Jika y_in }>0 \\
\text { Jika }-0 \leq \mathrm{y} \text { _in } \leq 0 \\
-1, \text { Jika y_in }<-0 \\
0,5, \text { jika }-0>1
\end{array}\right]
$$

Pada proses analisa diatas dapat disimpulkan bahwa $\mathrm{y}=0$ dan $\mathrm{t}=0$ maka iterasi selesai karena $\mathrm{y}=\mathrm{t}$ berarti tipe kepribadian adalah Guardian. Jika $\mathrm{y}=-1$ dan $\mathrm{t}=-1$ maka kepribadian mahasiswa tersebut Artisan, jika $\mathrm{y}=1$ dan $\mathrm{t}=1$ maka kepribadian Idealist dan jika $\mathrm{y}=0.5$ dan $\mathrm{t}=0.5$ maka kepribadian mahasiswa tersebut adalah rational.

Untuk melatih pola baru coba masukkan nilai $\mathrm{y}=-1$

\section{Data Ke-2}

Data Input $=1 ; 0 ; 1 ; 0 ; 1 ; 1 ; 1 ; 1 ; 1 ; 0 ; 1 ; 1 ; 1 ; 0 ; 0 ; 0 ; 1 ; 1 ; 0 ; 0 ; 1 ; 1 ; 0$

Target $=-1$

Algoritma Perceptron:

1. Inisialisasi (w2, w5-w7, w9-w11, w13-w23=0; w1, w3-w4, w8, w12=1; $b=0 ; \quad \alpha=1 ; \quad \Theta=0)$

2. Hitung respon untuk nilai output

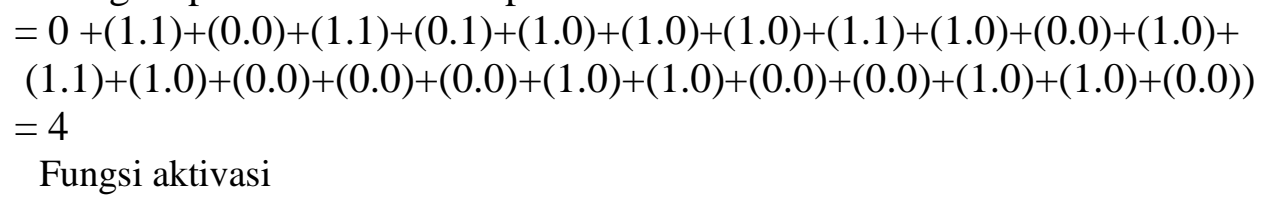

$$
\mathrm{Y}=0,\left[\begin{array}{c}
1, \text { Jika y_in }>0 \\
\text { Jika }-0 \leq \mathrm{y} \_ \text {in } \leq 0 \\
-1, \text { Jika y_in }<-0 \\
0,5, \text { jika }-0>1
\end{array}\right]
$$

(2)

Hasil aktivasi $\mathrm{y}=4, \mathrm{y} \neq \mathrm{t}$, karena $\mathrm{t}=-1$, maka dilakukan perubahan bobot dan bias. Sebagai berikut:

$\begin{array}{lllll}\text { w1 } & (\text { Baru })= & \mathrm{w}(\text { Lama })+\alpha * \mathrm{t} * \mathrm{Xi} & =1+1 *-1 * 1 & =0 \\ \mathrm{w} 2 & (\text { Baru })= & \mathrm{w}(\text { Lama })+\alpha * \mathrm{t} * \mathrm{Xi} & =0+1 *-1 * 0 & =0 \\ \mathrm{w} 3 & (\text { Baru })= & \mathrm{w}(\text { Lama })+\alpha * \mathrm{t} * \mathrm{Xi} & =1+1 *-1 * 1 & =0 \\ \mathrm{w} 4 & (\text { Baru })= & \mathrm{w}(\text { Lama })+\alpha * \mathrm{t} * \mathrm{Xi} & =1+1 *-1 * 0 & =1 \\ \mathrm{w} 5 & (\text { Baru })= & \mathrm{w}(\text { Lama })+\alpha * \mathrm{t} * \mathrm{Xi} & =0+1 *-1 * 1 & =-1 \\ \mathrm{w} 6 & (\text { Baru })= & \mathrm{w}(\text { Lama })+\alpha * \mathrm{t} * \mathrm{Xi} & =0+1 *-1 * 1 & =-1 \\ \mathrm{w} 7 & (\text { Baru })= & \mathrm{w}(\text { Lama })+\alpha * \mathrm{t} * \mathrm{Xi} & =0+1 *-1 * 1 & =-1 \\ \mathrm{w} 8 & (\text { Baru })= & \mathrm{w}(\text { Lama })+\alpha * \mathrm{t} * \mathrm{Xi} & =1+1 *-1 * 1 & =0 \\ \mathrm{w} 9 & (\text { Baru })= & \mathrm{w}(\text { Lama })+\alpha * \mathrm{t} * \mathrm{Xi} & =0+1 *-1 * 1 & =-1 \\ \mathrm{w} 10 & (\text { Baru })= & \mathrm{w}(\text { Lama })+\alpha * \mathrm{t} * \mathrm{Xi} & =0+1 *-1 * 0 & =0\end{array}$




$\begin{array}{lllll}\mathrm{w} 11 & (\text { Baru })= & \mathrm{w}(\text { Lama })+\alpha * \mathrm{t} * \mathrm{Xi} & =0+1 *-1 * 1 & =-1 \\ \mathrm{w} 12 & (\text { Baru })= & \mathrm{w}(\text { Lama })+\alpha * \mathrm{t} * \mathrm{Xi} & =1+1 *-1 * 1 & =0 \\ \mathrm{w} 13 \quad(\text { Baru })= & \mathrm{w}(\text { Lama })+\alpha * \mathrm{t} * \mathrm{Xi} & =0+1 *-1 * 1 & =-1 \\ \mathrm{w} 14 \quad(\text { Baru })= & \mathrm{w}(\text { Lama })+\alpha * \mathrm{t} * \mathrm{Xi} & =0+1 *-1 * 0 & =0 \\ \mathrm{w} 15 \quad(\text { Baru })= & \mathrm{w}(\text { Lama })+\alpha * \mathrm{t} * \mathrm{Xi} & =0+1 *-1 * 0 & =0 \\ \mathrm{w} 16 \quad(\text { Baru })= & \mathrm{w}(\text { Lama })+\alpha * \mathrm{t} * \mathrm{Xi} & =0+1 *-1 * 0 & =0 \\ \mathrm{w} 17 \quad(\text { Baru })= & \mathrm{w}(\text { Lama })+\alpha * \mathrm{t} * \mathrm{Xi} & =0+1 *-1 * 1 & =-1 \\ \mathrm{w} 18 \quad(\text { Baru })= & \mathrm{w}(\text { Lama })+\alpha * \mathrm{t} * \mathrm{Xi} & =0+1 *-1 * 1 & =-1 \\ \mathrm{w} 19 \quad(\text { Baru })= & \mathrm{w}(\text { Lama })+\alpha * \mathrm{t} * \mathrm{Xi} & =0+1 *-1 * 0 & =0 \\ \mathrm{w} 20 \quad(\text { Baru })= & \mathrm{w}(\text { Lama })+\alpha * \mathrm{t} * \mathrm{Xi} & =0+1 *-1 * 0 & =0 \\ \mathrm{w} 21 \quad(\text { Baru })= & \mathrm{w}(\text { Lama })+\alpha * \mathrm{t} * \mathrm{Xi} & =0+1 *-1 * 1 & =-1 \\ \mathrm{w} 22 \quad(\text { Baru })= & \mathrm{w}(\text { Lama })+\alpha * \mathrm{t} * \mathrm{Xi} & =0+1 *-1 * 1 & =-1 \\ \mathrm{w} 23 \quad(\text { Baru })= & \mathrm{w}(\text { Lama })+\alpha * \mathrm{t} * \mathrm{Xi} & =0+1 *-1 * 0 & =0\end{array}$

Setelah bobot baru didapat, maka akan dilanjutkan ke data berikutnya, jika output tidak sama dengan target $(\mathrm{y} \neq \mathrm{t})$, maka akan dilakukan perubahan bobot sampai didapatnya nilai output sama dengan target $(\mathrm{y}=\mathrm{t})$.

$\mathrm{b}(\mathrm{baru})=\mathrm{b}($ lama $)+\alpha * \mathrm{t}=0+1 *-1=-1$

\section{Data Ke-3}

Data Input $=1 ; 0 ; 0 ; 1 ; 0 ; 1 ; 0 ; 1 ; 0 ; 0 ; 0 ; 0 ; 0 ; 0 ; 0 ; 0 ; 0 ; 0 ; 1 ; 0 ; 0 ; 0 ; 0$

Target : 0

Algoritma Perceptron:

1. Inisialisasi (w1-w3, w8, w10, w12, w14-w16, w19-w20, w23 = 0; w4 =1; w5w7, w9, w11, w13, w17-w18, w21-w22 =-1 b= -1; $\alpha=1 ; \Theta=0)$

2. Hitung respon untuk unit output

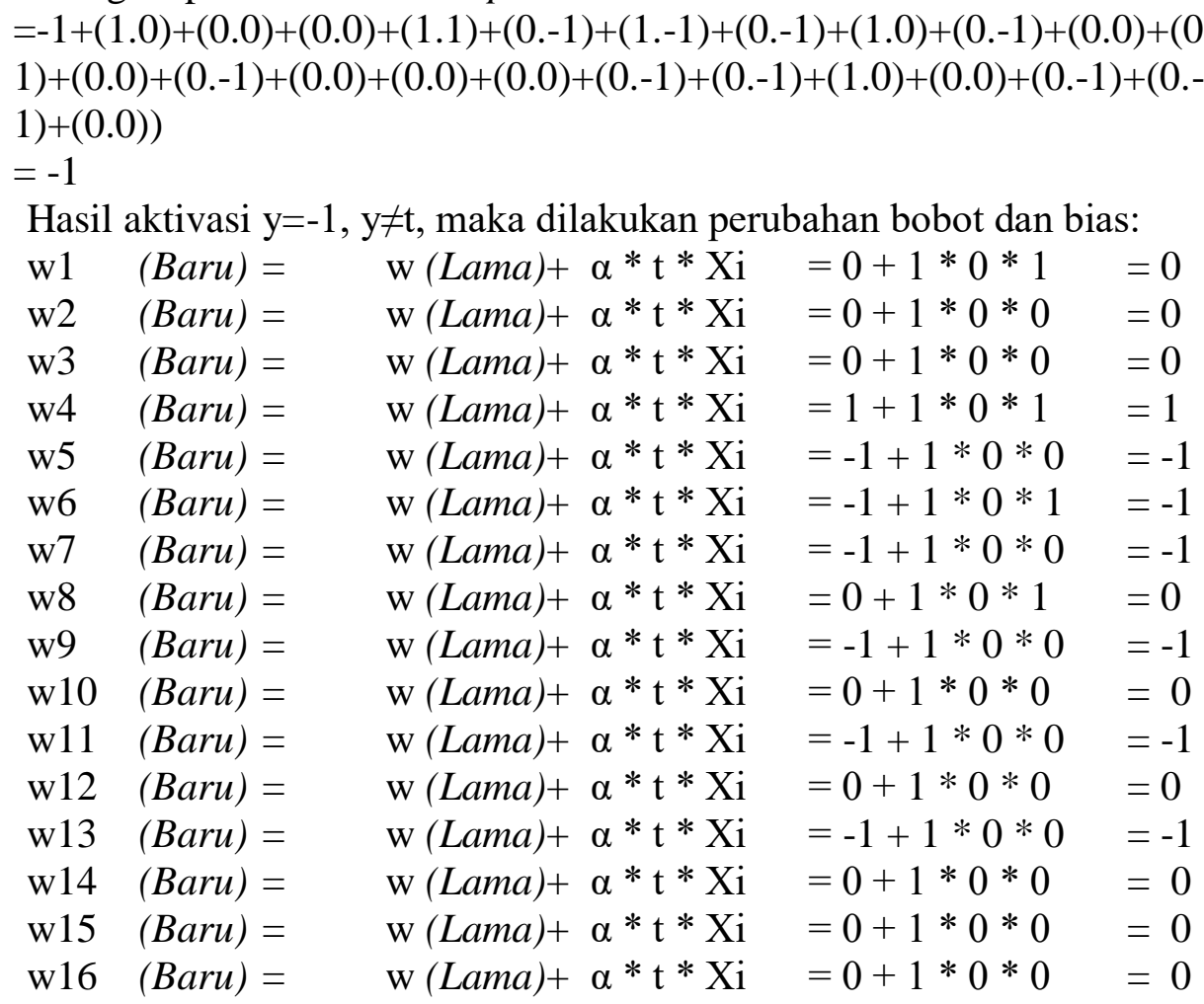




$\begin{array}{rllll}\mathrm{w} 17 & (\text { Baru })= & \mathrm{w}(\text { Lama })+\alpha * \mathrm{t} * \mathrm{Xi} & =-1+1 * 0 * 0 & =-1 \\ \mathrm{w} 18 & (\text { Baru })= & \mathrm{w}(\text { Lama })+\alpha * \mathrm{t} * \mathrm{Xi} & =-1+1 * 0 * 0 & =-1 \\ \mathrm{w} 19 & (\text { Baru })= & \mathrm{w}(\text { Lama })+\alpha * \mathrm{t} * \mathrm{Xi} & =0+1 * 0 * 1 & =0 \\ \mathrm{w} 20 & (\text { Baru })= & \mathrm{w}(\text { Lama })+\alpha * \mathrm{t} * \mathrm{Xi} & =0+1 * 0 * 0 & =0 \\ \mathrm{w} 21 & (\text { Baru })= & \mathrm{w}(\text { Lama })+\alpha * \mathrm{t} * \mathrm{Xi} & =-1+1 * 0 * 0 & =-1 \\ \mathrm{w} 22 & (\text { Baru })= & \mathrm{w}(\text { Lama })+\alpha * \mathrm{t} * \mathrm{Xi} & =-1+1 * 0 * 0 & =-1 \\ \mathrm{w} 23 & (\text { Baru })= & \mathrm{w}(\text { Lama })+\alpha * \mathrm{t} * \mathrm{Xi} & =0+1 * 0 * 0 & =0 \\ \mathrm{~b}(\text { baru })=\mathrm{b}(\text { lama })+\alpha * \mathrm{t}=-1+1 * 0=-1 & & \end{array}$

\subsection{Implementasi Jaringan Syaraf Tiruan Menggunakan Matlab}

Tahapan ini akan dilakukannya penerapan Jaringan Syaraf Tiruan untuk Tipe Kepribadian. Guardian-Artisan-Idealist-Rational mahasiswa menggunakan Algoritma Perceptron. Matlab adalah perangkat lunak yang digunakan dalam alat komputasi yang menggunakan matriks dan vektor. Hasil implementasi dengan menggunakan software matlab ini merupakan hasil pengujian terhadap perhitungan manual.

\subsubsection{Tahap Pengujian}

Tahap pengujian menggunakan data set training yang telah disiapkan dengan aplikasi Matlab. Pada tahap ini akan dilakukan pengujian yang masingmasing pengujian memiliki jumlah pola berbeda. Adapun detail pengujian data dapat dilihat pada tabel 5

Tabel 5. Data Pengujian

\begin{tabular}{|c|c|}
\hline Pengujian & Pola Masukan \\
\hline Pengujian 1 & 2 \\
\hline Pengujian 2 & 5 \\
\hline Pengujian 3 & 8 \\
\hline Pengujian 4 & 10 \\
\hline Pengujian 5 & 15 \\
\hline Pengujian 6 & 20 \\
\hline Pengujian 7 & 25 \\
\hline Pengujian 8 & 30 \\
\hline
\end{tabular}

Penentuan tipe kepribadian dengan penerapan Jaringan Syaraf Tiruan menggunakan metode Perceptron yaitu dengan menentukan targetnya. Dalam hal ini target adalah tipe kepribadian Guardian-Artisan-Idealist-Rational. Setelah target ditentukan, dilanjutkan dengan pola data yang akan dikenali melalui proses pembelajaran. Proses ini dilakukan menggunakan data set training adalah salah satu proses yang dapat dilakukan. Program ini tidak akan bekerja apabila semua output sama dengan target atau iterasi (epoch) telah mencapai nilai maksimum.

\subsubsection{Memulai Aplikasi Matlab}

Tahap pertama yang dilakukan adalah dengan menjalankan software matlab, kemudian akan muncul beberapa form seperti gambar dibawah ini. 


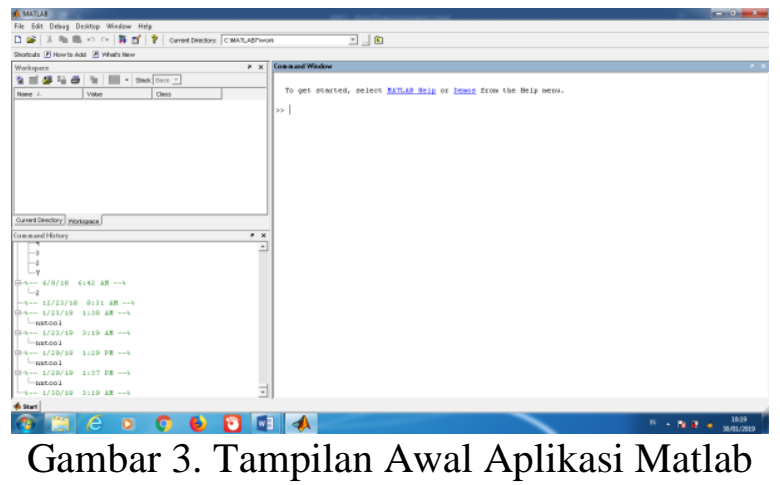

Matlab mempunyai 6 buah jendela yaitu command window (jendela perintah), command history (jendela daftar perintah), launch pad, jendela help, jendela directory, dan jendela workspase.

\subsubsection{Tahap Testing}

Pada tahap ini akan dilakukan proses testing (pengujian) berdasarkan analisa proses dengan menggunakan Software Matlab. Menentukan Kepribadian Mahasiswa dapat ditentukan melalui proses pengujian dalam penerapan Jaringan Syaraf Tiruan

\section{Pengujian 1; dengan 2 pola Masukan}

Variabel input:

Data $1: 1 ; 0 ; 1 ; 1 ; 0 ; 0 ; 0 ; 1 ; 0 ; 0 ; 0 ; 1 ; 0 ; 0 ; 0 ; 0 ; 0 ; 0 ; 0 ; 0 ; 0 ; 0 ; 0$

Data $2: 1 ; 0 ; 1 ; 0 ; 1 ; 1 ; 1 ; 1 ; 1 ; 0 ; 1 ; 1 ; 1 ; 0 ; 0 ; 0 ; 1 ; 1 ; 0 ; 0 ; 1 ; 1 ; 0$

$\mathrm{b}=0, \mathrm{w}=0, \mathrm{t}=0,-1$

Untuk melihat hasil pengujian 1 menggunakan Matlab, dapat dianalisa melalui gambar dibawah.

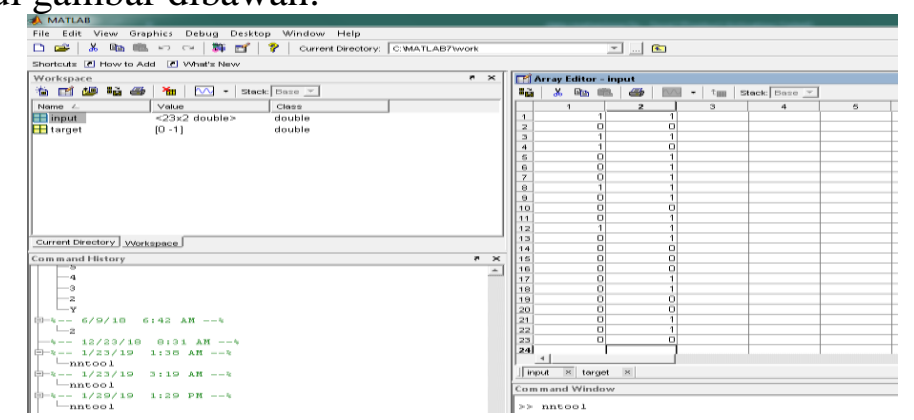

Gambar 4. Variabel input pengujian I

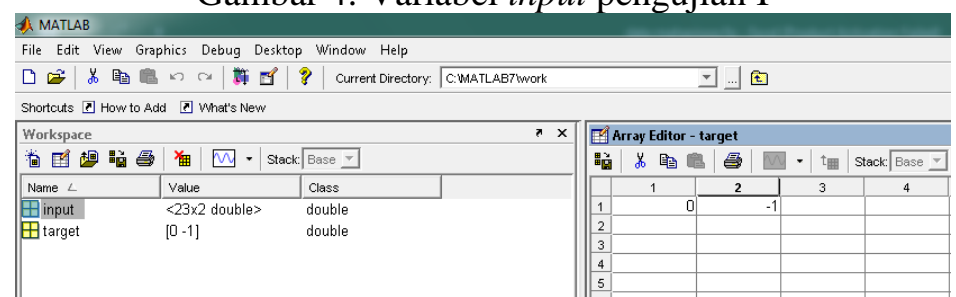

Gambar 5. Variabel Target Pengujian 1

Gambar 4 dan 5 adalah data diambil dari 2 data sampel dengan dua target yaitu 0 dan -1 . untuk pengujian data dengan 2 pola masukan. Selanjutnya hasil training atau output dalam bentuk grafik dapat dilihat pada gambar 6 . 


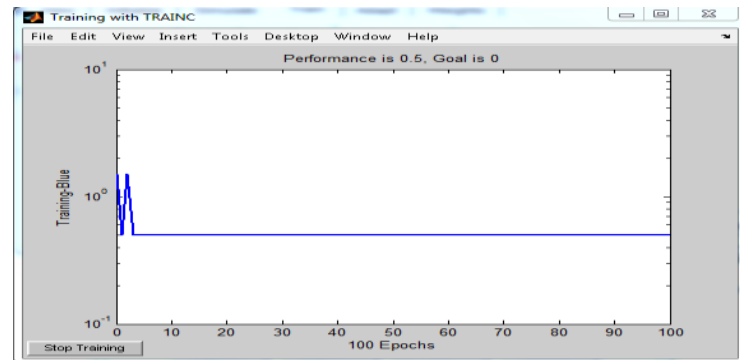

Gambar .6. Hasil Pengujian 1

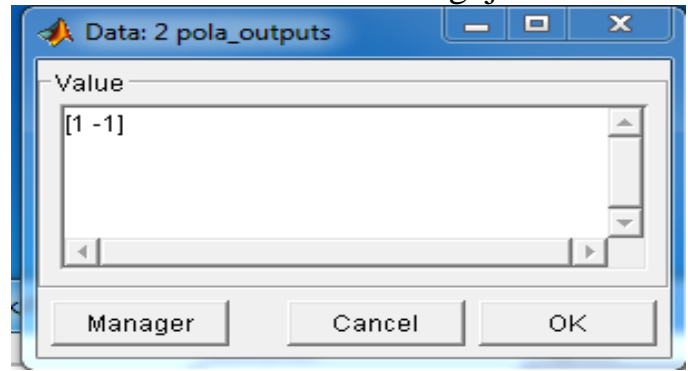

Gambar 7. Hasil Output Pengujian 1

Berdasarkan hasil pengujian pada gambar 5 dan Gambar 6 maka pengujian dengan 2 pola masukan didapat performance 0.5 dan goal 0 , yang mana pola data dikenali pada epoch ke 100 .

Pengujian 2; dengan 5 pola masukan

Variabel input:

Data $1: 1 ; 0 ; 1 ; 1 ; 0 ; 0 ; 0 ; 1 ; 0 ; 0 ; 0 ; 1 ; 0 ; 0 ; 0 ; 0 ; 0 ; 0 ; 0 ; 0 ; 0 ; 0 ; 0$

Data $2: 1 ; 0 ; 1 ; 0 ; 1 ; 1 ; 1 ; 1 ; 1 ; 0 ; 1 ; 1 ; 1 ; 0 ; 0 ; 0 ; 1 ; 1 ; 0 ; 0 ; 1 ; 1 ; 0$

Data $3: 1 ; 0 ; 0 ; 1 ; 0 ; 1 ; 0 ; 1 ; 0 ; 0 ; 0 ; 0 ; 0 ; 0 ; 0 ; 0 ; 0 ; 0 ; 1 ; 0 ; 0 ; 0 ; 0$

Data $4: 1 ; 0 ; 1 ; 1 ; 1 ; 1 ; 0 ; 1 ; 1 ; 1 ; 1 ; 1 ; 1 ; 0 ; 0 ; 1 ; 0 ; 1 ; 1 ; 0 ; 1 ; 1 ; 1$

Data $5: 1 ; 1 ; 1 ; 0 ; 1 ; 0 ; 0 ; 1 ; 1 ; 1 ; 1 ; 1 ; 1 ; 0 ; 1 ; 1 ; 1 ; 1 ; 1 ; 0 ; 0 ; 1 ; 1$

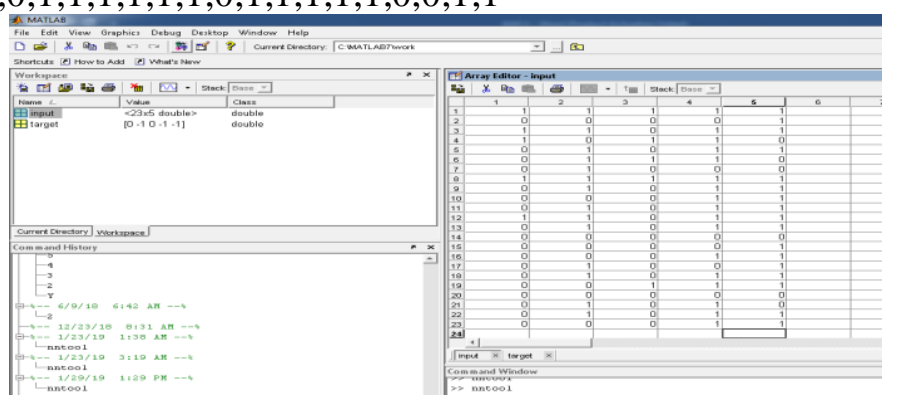

Gambar 8. Variabel Input Pengujian 2

Gambar 9 adalah data diambil dari 5 data sampel untuk pengujian data dengan 5 pola masukan,

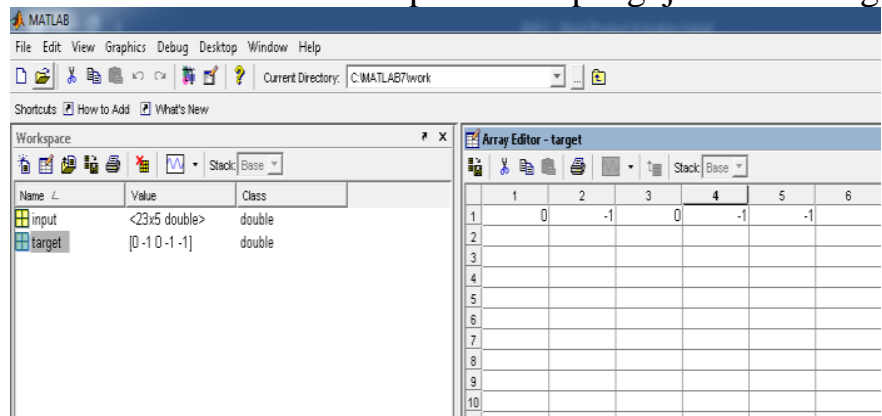

Gambar 9. Variabel Target Pengujian 2 
Pada 5 data sampel terdapat masing-masing nilai target yang berbeda, untuk 5 data sampel bernilai $0,-1,0,-1,-1$ training atau output dapat dilihat melalui bentuk grafik pada gambar 10

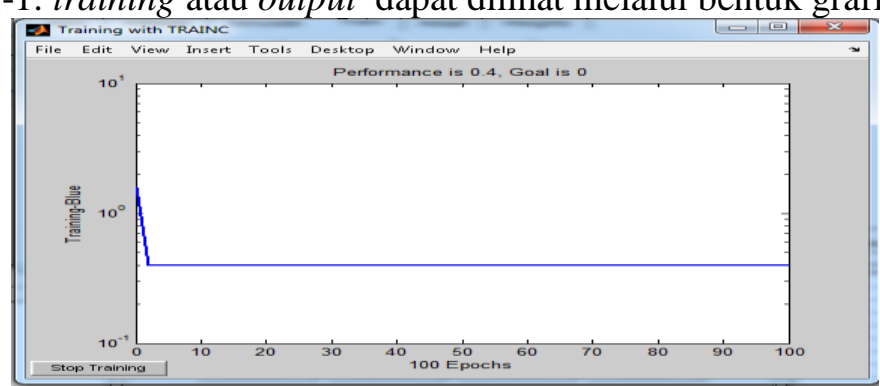

Gambar 10. Hasil Pengujian 2

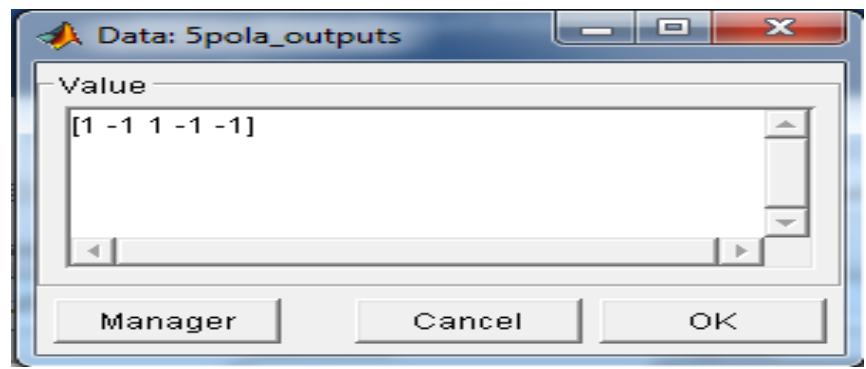

Gambar 11. Hasil Output Pengujian 2

Berdasarkan hasil pengujian pada gambar 9 dan Gambar 10 maka pola data dikenali pada epoch ke 100 dari hasil pengujian 5 pola masukan didapat performance 0.4 dan goal 0

Tabel 6. Perbandingan Hasil Performance

\begin{tabular}{|c|c|c|c|}
\hline No & Pengajuan & Pola Masukan & Performance \\
\hline 1 & Pengujian 1 & 2 & 0.5 \\
\hline 2 & Pengujian 2 & 5 & 0.4 \\
\hline 3 & Pengujian 3 & 8 & 0.25 \\
\hline 4 & Pengujian 4 & 10 & 0.3 \\
\hline 5 & Pengujian 5 & 15 & 0.3 \\
\hline 6 & Pengujian 6 & 20 & 0.225 \\
\hline 7 & Pengujian 7 & 25 & 0.24 \\
\hline 8 & Pengujian 8 & 30 & 0.25 \\
\hline
\end{tabular}

Setelah dilakukan pengujian untuk beberapa pola masukan yakni dengan 2 pola , 5 pola , 8 pola 10 pola , 15 pola ,20 pola , 25 pola dan terakhir 30 pola, dimana untuk penelitian ini ada 30 pola masukan ,maka di dapat hasil perbandingan dan hasil ini sesuai dengan perhitungan algoritma perceptron jadi bisa terlihat bahwa dalam kelas artificial intelligen yang terdiri dari 30 mahasiswa kepribadian ayang dominan adalah tipe artisan dan idealist sehingga hasil peneloatian ini bisa disarankan untuk mengembangkan pola mengajar bagi dosen AI.

\section{Kesimpulan}

Pengelompokan Tipe Kepribadian Mahasiswa pada Fakultas Ilmu Komputer adalah 5 mahasiswa dengan kepribadian Guardian, 11 mahasiswa dengan kepribadian Artisan, 11 mahasiswa dengan tipe kepribadian Idealist dan 3 mahasiswa dengan kepribadian Rational. Tingkat performance adalah 0.5 yang mana dicapai pada epoch ke 100 merupakan hasil pengujian pertama melalui 2 pola baru. Ditemukan bahwa 
ketepatan data lebih baik dalam pelatihan yang menggunakan input sedikit daripada innput yang banyak.

Pada penelitian ini dapat dilihat cara mengajar yang sesuai dengan kepribadian mahasiswa adalah pada tipe guardian, mahasiswa menyukai pembelajaran yang detail, tepat dan nyata. Tipe kepribadian Artisan, menyukai pembelajaran persentase dan yang melibatkan aksi. Untuk tipe kepribadian Idealist menyukai pembelajaran yang individu dan menulis essay. Tipe kepribadian Rational menyukai penjelasan yang didasarkan pada logika. Deskripsi dari kekempat output tersebut memudahkan dosen untuk menilai anak didiknya dengan didukung penilaian secara softskill dan dosen lebih inovatif untuk mengembangkan cara mengajar sesuai dengan dominan atau gabungan kepribadian yang ada di dalam kelas .

\section{Daftar Pustaka}

[1] Y. A. Lesnussa, S. Latuconsina, and E. R. Persulessy, "Aplikasi Jaringan Saraf Tiruan Backpropagation untuk Memprediksi Prestasi Siswa SMA ( Studi kasus: Prediksi Prestasi Siswa SMAN 4 Ambon )," vol. 11, no. 2, pp. 149-160, 2015.

[2] L. L. Van Fc, "Klasifikasi Gaya Belajar Visual-Audiotory-Kinesthetic (V-A-K) Mahasiswa Berbasis JST Menggunakan Algoritma Perceptron," J. Teknol. Inf. Komun. Digit. Zo. Vol. 7 , Nomor 1, Februari 2016 26-30, vol. 7, no. February 1st, pp. 26-30, 2016.

[3] K. Fitryadi, "Pengenalan Jenis Golongan Darah Menggunakan Jaringan Syaraf Tiruan Perceptron," vol. 7, 2016.

[4] M. U. Musthofa, Z. K. Umma, and A. N. Handayani, "Analisis Jaringan Saraf Tiruan Model Perceptron Pada Pengenalan Pola Pulau di Indonesia," vol. 11, no. 1, pp. 89-100, 2017.

[5] M. Nur, L. Achmad, H. Anik, and N. Handayani, "Aplikasi jaringan syaraf tiruan metode perceptron pada pengenalan pola huruf hijaiyah ( huruf arab )," vol. 2, no. 1, 2017.

[6] Y. Nagao, "Classification of MathML Expressions Using Multilayer Perceptron," pp. 133-136, 2017.

[7] M. Yanto, T. Informatika, and F. I. Komputer, "Penerapan jaringan syaraf tiruan dengan algoritma perceptron pada pola penentuan nilai status kelulusan," vol. 5, no. 2, pp. 7987, 2017.

[8] F. M. Bayat, M. Prezioso, B. Chakrabarti, I. Kataeva, and D. Strukov, "Memristor-Based Perceptron Classifier : Increasing Complexity and Coping with Imperfect Hardware," no. c, 2017.

[9] M. Fachrie and A. P. Wibowo, "Jaringan syaraf tiruan untuk memprediksi kinerja satpam," vol. 3, no. 1, pp. 46-51, 2018.

[10] J. J. Siang, Jaringan Syaraf Tiruan dan Pemogramannya Menggunakan Matlab. 2009.

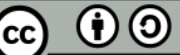

Digital Zone: Jurnal Teknologi Informasi dan Komunikasi is licensed under a Creative Commons Attribution International (CC BY-SA 4.0) 